\title{
Verbs of pain and accusative subjects in Romanian
}

\author{
Marleen Van Peteghem \\ Ghent University - Contragram $\Omega$
}

\begin{abstract}
Verbs of pain in Romanian such as durea 'ache', ustura 'burn', and furnica 'itch' assign the accusative to their experiencer arguments, unlike other Romance languages, where the experiencer is dative-marked. The use of the accusative raises interesting problems in that it gives rise to a mismatch between the hypothesis on therax of inalienability in Romance in Generative Grammar (Guéron 1985) Burzio's (1986) Generalizatio $P$ is article shows that the inversed nominative NP denoting the body part does not show subject properties, and that the accusative experiencer in sentence initial position does not show object properties, but instead displays subject properties, just like the dative in similar constructions. However, the difference between accusative and dative subjects in this construction is that the accusative is assigned to verb arguments and is a lexical case, whereas the dative is assigned to external possessors and is an inherent case. Surprisingly, the argument status of the accusative experiencer makes it even more subject-like than the dative experiencer, which is an adjunct and is dependent on the presence of an internal argument triggering verb agreement, whereas the accusative subject can also occur without an internal argument or with a locative PP.
\end{abstract}

\section{o. Introduction ${ }^{1}$}

The argument structure of verbs expressing pain in Romanian (e.g. durea 'ache', ustura 'burn, irritate, arde 'burn', etc.) raises interesting problems both from a comparative and a theoretical point of view. These verbs take two arguments: a theme denoting the aching body part and an experiencer denoting the person who feels the pain. As in other Romance languages, the theme is encoded as a grammatical subject triggering verb agreement in Romanian; however, the experiencer

1. I would like to express my gratitude to two anonymous reviewers for their insightful remarks. Needless to say, I am responsible for all remaining imperfections. 
receives accusative case (1), whereas in languages such as Spanish, French and Italian it is dative-marked (2).
(1) a. îl
doare cap-ul
him.Acc hurts head-the
b. Îl arde piele-a
him.ACC burns skin-the
(He has a headache)
(His skin is burning)
(2) a. Sp. Le duele la
cabeza
him.DAT hurts the head (He has a headache)
b. Fr. La peau lui brûle
the him.Dat burns (His skin is burning)
c. It. Gli prude la pelle
him.DAT itches the skin (His skin is itching)

The use of the accusative instead of the dative in the Romanian examples in (1) is interesting because it results in a mismatch between the following two hypotheses put forward in Generative Grammar:

a. the hypothesis on the syntax of inalienable possession, as it was formulated by J. Guéron (1983, 1985, 2003, 2007), J.-R. Vergnaud \& M.L. Zubizaretta (1992) and J. Herschensohn (1992);

b. the Unaccusativity hypothesi $\Omega$ st formulated by D.M. Perlmutter (1978) within the framework of Relational Grammar, and later adopted by L. Burzio (1981, 1986) in Generative Grammar in what is generally called "Burzio's Generalization”.

According to hypothesis (a), the definite article of the body part NP is bound by the experiencer pronoun, which is only possible if the latter c-commands the former. Therefore the body part NP in subject position is to be analyzed as an internal argument of the verb, raised to subject position, and consequently the verb has to be unaccusative. However, according to Burzio's Generalization, unaccusative verbs are unable to assign accusative case. Therefore, the experiencer pronoun should occur in the dative as in other Romance languages, and not in the accusative as in Romanian.

The main focus of this article is to account for the atypical case assignment in the structure $\left[m \breve{a}_{\text {ACC }} V_{\text {pain }} \mathrm{NP}_{\text {body part }}\right.$ ] in Romanian. I will argue that the accusative nominal in (1) shows subject properties, just like the dative in similar constructions with other types of verbs of pain. The difference between accusative and dative subjects is that the accusative is assigned to a verb argument, regardless of the syntactic encoding of the theme argument, whereas the dative is not a verb argument, but an external possessor, hence an argument of the noun denoting the body part, and therefore highly dependent on the syntactic encoding of the body 
part NP. This leads to the surprising conclusion that in the construction under investigation the accusative is less dependent on the morpho-syntactic encoding of other verb arguments than the dative and constitutes empirical evidence against the widely accepted idea that the accusative is basically a dependent case.

The article is structured as follows. Section 1 discusses the mismatch between the two hypotheses mentioned above and shows that the Romanian data violate Burzio's Generalization. Section 2 explores which verbs enter into the accusative construction and examines how this structure relates to the other argument structures of these verbs. Section 3 investigates the syntactic behavior of the two arguments of the construction in (1); more specifically, it addresses the question to what extent they display either object or subject behavior. Finally, Section 4 studies the competition between accusative and dative as case marking of quirky subjects of verbs of pain in Romanian.

\section{The Inalienable Possession Hypothesis vs. the Unaccusativity Hypothesis}

\subsection{The syntax of inalienable possession}

J. Guéron (1983, 1985, 2003), J.-R. Vergnaud \& M.L. Zubizaretta (1992) and J. Herschensohn (1992), among others, showed that in French the main syntactic property of inalienable possession is the presence of a definite article functioning as a bound anaphor. ${ }^{2}$ The antecedent of this anaphor is the pronoun or the NP denoting the possessor, which can occur either as the indirect object, direct object or subject of the verb. In the corresponding structures in Romanian, the pronoun or NP can be either in the dative (3a), the accusative (3b), the nominative or be omitted (3c), since Romanian is a PRO-drop language. As for the anaphoric NP denoting the inalienable referent, it mostly occurs as a direct object (3a), but also within a PP (3b) or even as a subject (3d).

$$
\begin{aligned}
& \text { a. Maria } \mathrm{i}_{\mathrm{i}^{-}} \text {a mângîat mâna } \\
& \text { Mary him.DAt has stroked hand-the } \\
& \text { (Mary stroked his hand) }
\end{aligned}
$$

2. The use of the indefinite article is equally possible (cf. M.-O. Junker \& F. Martineau 1987: 196):

Edgar se lava soigneusement une oreille, puis l'autre.
Edgar himself
'Edgar carefully washed one ear, then the other'



b. Maria $1_{i^{-}} \quad$ a luat de mână ${ }_{i}$ Mary him.ACC has taken by hand (Mary took him by the hand)
c. $\left[\right.$ Maria $\left._{i}\right]$ a ridicat mân- $\mathrm{a}_{\mathrm{i}}$ Maria has raised hand-the (Mary raised her hand)
d. Immi $_{i}$ curge nas-ul ${ }_{i}$ me.DAT flows nose-the (I have a runny nose)

This anaphora is not coreferential, but a kind of intraphrastic associative anaphor (cf. M. Van Peteghem 2006b). ${ }^{3}$ As argued by the authors mentioned above, it is syntactically bound, which means that it is c-commanded by the antecedent, like reflexives. ${ }^{4}$ In other words, the anaphoric NP denoting the body part must occur in a syntactic position that is locally c-commanded by the antecedent.

If this hypothesis is correct, the anaphoric NP cannot occur in subject position, since the subject c-commands all other NPs of the clause. Therefore, a sentence such as (3d), where the anaphoric NP is the subject, should be ruled out. Nevertheless, both in Romanian and in other Romance languages, such examples do occur (cf. (1), (2)), although this structure is not productive in all of them. In French, for instance, it is restricted to a few particular verbs (cf. A.-M. Spanoghe 1995; E. König \& M. Haspelmath 1998:539).

Nevertheless, according to J. Guéron $(1983,1985)$, the examples (4a-b) do not violate the bound anaphora hypothesis, but can be explained by the fact that the subject is a deep object raised to subject position. In line with L. Burzio (1981), she argues that the structure in $(4 a-b)$ is unaccusative. Therefore the verb cannot assign the accusative case to the object, which raises into subject position in order

3. For more details on associative anaphors, see M. Riegel (1994), C. Schnedecker et al. (1994) and G. Kleiber (1999).

4. J.-R. Vergnaud \& M.L. Zubizaretta (1992: Note 18) describe the structural relation between the dative and the possessee NP in terms of $\mathrm{m}$-command, defined in the following way: " $\mathrm{x}$ $\mathrm{m}$-commands $\mathrm{y}$ iff $\mathrm{x}$ does not dominate $\mathrm{y}$ and every maximal projection $\mathrm{z}$ that dominates $\mathrm{x}$ dominates y." 
to receive nominative case (J. Guéron 1985:51). As a consequence, these verbs have to resort to the dative case for the second internal argument (cf. M. Van Peteghem 2006a).

This analysis accounts perfectly for the examples in (2), (3d), (4), in which the possessor pronoun is dative marked, but not for those of the type of mă doare capul in Romanian, in which an apparently unaccusative verb assigns accusative case to its second argument. In other words, the accusative structure in (1) gives rise to an inconsistency between the inalienable possession hypothesis as elaborated by J. Guéron (1983, 1985, 2003), J.-R. Vergnaud \& M.L. Zubizaretta (1992) and J. Herschensohn (1992) on the one hand and Burzio's Generalization on the other.

\subsection{The Unaccusativity Hypothesis and Burzio's (1986) Generalization}

The Unaccusativity Hypothesis of D.M. Perlmutter (1978), reformulated in L. Burzio's Generalization $(1981,1986)$ states "that a verb that does not assign an external $\theta$-role to its subject does not assign structural accusative Case to an object and conversely" (cf. E. Reuland 2000b:1). In the absence of an external argument able to occupy the subject position, the internal argument moves into subject position, triggering verb agreement, and therefore the verb can no longer assign accusative case.

However, as shown in several studies, counter-examples can be found in various languages. The most discussed counter-evidence comes from the impersonal construction, as in French (5a) or Italian (5b). In this construction, the internal argument does not move into subject position, which is filled by an expletive pronoun (or is empty in pro-drop languages).

(5) a. Il est arrivé un accident

It is arrived an accident

(An accident has happened)

b. Si leggerà volentieri alcuni articoli. (H. Haider 2000:44) si.IMP read.3.sG.FUT voluntarily several articles

(One will voluntarily read several articles)

In its original version, the Unaccusative Hypothesis was introduced to account for one-place predicates, such as intransitives or passives. However, in later studies it has been extended to two-place predicates lacking an external $\theta$-role, such as psychological verbs of the piacere class, which take a theme and an experiencer argument (cf. A. Belletti \& L. Rizzi 1988). However, as shown by various authors, one of the three classes of psychological verbs distinguished by A. Belletti \& L. Rizzi, the preoccupare class, is also inconsistent with Burzio's Generalization. Binding 
facts indeed show that the subject arguments of such verbs are in a lower position than the objects (cf. A. Belletti \& L. Rizzi 1988:313). The subject is therefore to be analyzed as a derived subject, raised from a VP-internal position. Consequently, the constructions in (6) should be unaccusative and their verbs should not be able to assign accusative case, which they do.

(6) a. Questi pettegolezzi su di se preoccupano Gianni these gossips on of himself worry Gianni più di ogni altra cosa more than each other thing (This gossip about himself worries Gianni more than anything else)

b. Stories about herself $f_{i}$ rarely annoy her ${ }_{i}$ profoundly. (H. Haider 2000:36)

Various authors (cf. E. Reuland 2000b; A. Marantz 2000; H. Haider 2000) have shown that the problems originate from the fact that Burzio's Generalization is "cross-modular" (cf. H. Haider 2000:33) in that it relates case marking to argument structure. The assignment of an external semantic role to the subject is claimed to be a condition for the assignment of a structural accusative case and vice versa. Furthermore, as shown by A. Marantz (2000), Burzio's Generalization appeals to two independently motivated principles: (i) the requirement that sentences have subjects (the "Extended Projection Principle, cf. N. Chomsky 1986: 4), according to which the internal argument should move into subject position in the absence of an external $\theta$-role (cf. the "nominative first" condition, E. Reuland 2000b: 3), and (ii) the hypothesis of the dependency of the accusative on the nominative case. In fact, a language such as Russian, which has morphological cases, shows that neither of these principles is universal: internal arguments do not necessarily move into subject position and accusative case can be assigned without a nominative (cf. (7)). Furthermore, external arguments can be demoted from subject position and receive quirky case, as in the Russian example (8b), where the external argument of an unergative verb receives quirky dative case and the verb takes the reflexive impersonal form.

(7) Menja tošnit.

(Perlmutter \& Moore 2002)

me.ACC nauseate.3sg

(I feel nauseous)

(8) a. Ja zdes xorošo rabotaju

I here well work

(I always work well here)

b. Mne zdes' xorošo rabotaet-sja

me.DAT here well work-REFL

(I can work well here) 
Within the framework of generative grammar, various solutions have been proposed to account for the above-mentioned counter-evidence (e.g. the papers collected in E. Reuland 2000a; and also E. Woolford 2003; H. Bennis 2004, etc.). There is a general consensus that the assignment of the nominative case to internal arguments is not related to the unability of verbs to license the accusative case, but to the requirement that an object gets the nominative case when there is no nominative subject (e.g. L. Burzio 2000; H. Haider 2000; E. Woolford 2003). However, this reformulation of Burzio's Generalization does not account for the Russian dative subject construction in (8b), nor for the dative subject constructions in Faroese in (9), in which a dative subject co-occurs with an accusative object (cf. M. Barnes 1986; E. Woolford 2003).

(9) Mær líkar henda filmin.

(Barnes 1986: 12)

Me.DAT likes this film.ACC

(I like this film)

In what follows we will show that it cannot account for the impersonal constructions of verbs of pain in Romanian either.

\section{Verbs of pain and their argument structures}

Before examining the accusative structure in (1), I will first explore which verbs of pain can occur in it. These are not very numerous since, as will be shown in Section 4 , most verbs of pain occur with a dative experiencer, as in the other Romance languages.

A. Şerbănescu (1999) provides a list of the following nine verbs of pain assigning the accusative to their second arguments, to which I add one more verb: a pişca 'pinch'. In my corpus research on the structure $\left[m a \breve{~} \mathrm{~V}_{\text {pain }} \mathrm{NP}_{\text {body part }}\right]$ I have not found any other verbs. 5

(10) arde 'burn', durea 'ache', furnica 'tingle', frige 'burn', gâdila 'tickle', înţepa 'sting', mânca (here 'itch', primary meaning 'eat'), strânge 'tighten', ustura 'burn'

As in other languages, most of these verbs are drawn from other semantic fields, have various other argument structures, and their use as a verb of pain is the result of metaphorization (cf. A. Bonch-Osmolovskaya et al. 2007). Only few of them are verbs of pain in their primary use.

5. Since all electronic corpora available for Romanian (cf. Sketchengine) proved to be too limited, I used the Romanian version of Google (google.ro) as a corpus. 
The most basic verb of pain is without any doubt durea 'ache', which can only be used with two arguments. Four other verbs belong to the semantic field of pain in their primary use: a ustura 'burn', gâdila 'tickle', inţepa 'prick, sting' and pişca 'to pinch'. However, they differ from durea in that they are often used with an external argument, denoting either the person or another stimulus which causes the pain and occurs in subject position. The body part is then encoded as a direct object and the experiencer as a dative pronoun. This gives rise to an interesting alternation, illustrated in (11)-(12): the same NP denoting a body part can occur as a direct object in the structure with an external argument (11), or as a subject in the structure without an external argument (12).

(11) a. Flăcări-le erau atât de aproape, încât simţea-m cum cenuş-a flames-the were so of close that felt-1 how ash-the îmi gâdila gât-ul me.DAT tickled throat-the (The flames were so close that I felt how the ashes tickled my throat)

b. Atunci când mâini-le voastre se întind pentru îmbrăţişare, nu then when hands-the your REF stretch for hugging not sunt altceva decât tentacule murdare care îmi înţeapă spate-le are other than tentacles dirty which me.DAT sting back-the (When your hands stretch to hug, they are nothing but dirty tentacles which sting my back)

c. Stropi-i de şampanie lunecă pe gât, iar bulele splashes-the of champagne are slipping by throat and bubbles-the îmi pişcă limb-a me.DAT pinch tongue-the (Splashes of champagne are slipping down my throat and the bubbles tickle my tongue)

(12) a. Dacă te gâdilă gât-ul, scarpină-ţi ureche-a! if you.ACC tickles throat-the scratch-you.DAT ear-the (If your throat tickles, scratch your ear!)

b. De câteva zile mă înţeapă spate-le în parte-a stângă for several days me.Acc sting back-the in side-the left (For several days my back has been hurting on the left side)

c. Mă pişcă limb-a şi buze-le de la sare me.ACC sting tongue-the and lips-the from salt (My tongue and lips sting because of the salt)

This alternation is close to the causative alternation. However, the difference with the latter alternation is that in the canonical causative alternation an intransitive 
construction alternates with a transitive one, whereas the alternation illustrated in (11)-(12) involves two transitive constructions.

The other five verbs are not directly linked to the field of pain in their primary meaning and express pain by metaphorization. One of them, furnica 'tingle', is basically an intransitive motion verb meaning 'to swarm, to move around in a quick and chaotic way like ants. ${ }^{6}$ Used as a verb of pain, it never takes an external argument and can only occur in the same argument structure as durea 'ache', with an experiencer and a theme (13b).
a. Sute
de oameni furnicau în jurul
biserici-i
hundreds of people ant.v in round-the church.GEN-DEF (Hundreds of people were moving around the church)
b. Mă furnică picioare-le
me.ACC itch feet-the
(My feet are itching)

The other four come from completely different semantic fields: frige 'grill, roast' and arde 'burn' are typical verbs of physical change entering into the causative alternation, strânge means 'pull together' and can be included in the class of verbs of deformation (cf. A. Bonch-Osmolovskaya et al. 2007:114), while mânca 'eat' turns into a verb of destruction when used as a verb of pain.

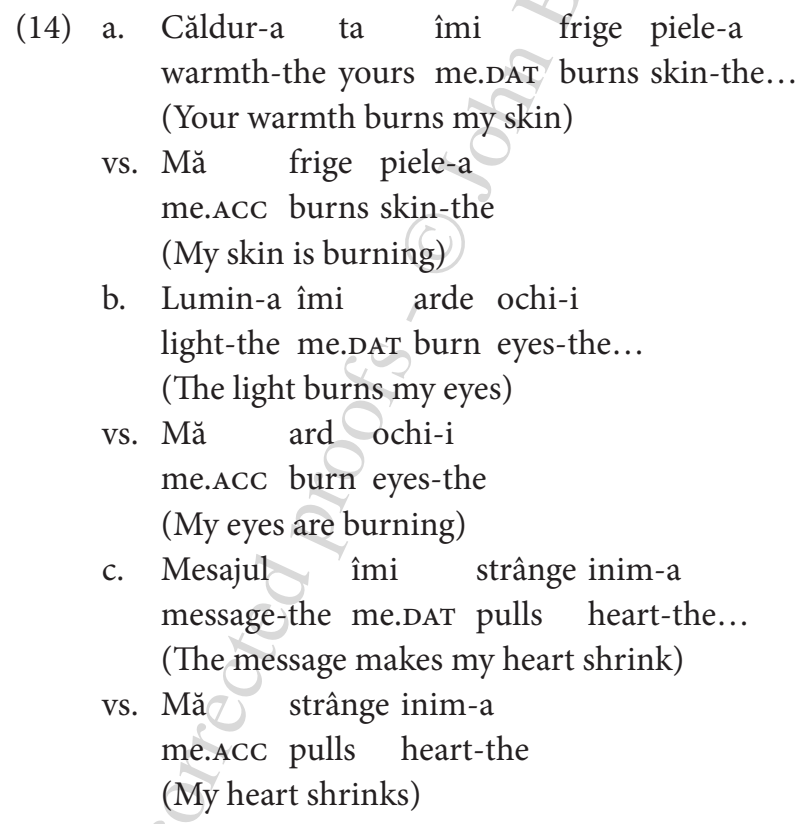

6. The verb furnica derives from Lat. formicare (cf. o furnică 'an ant'). 


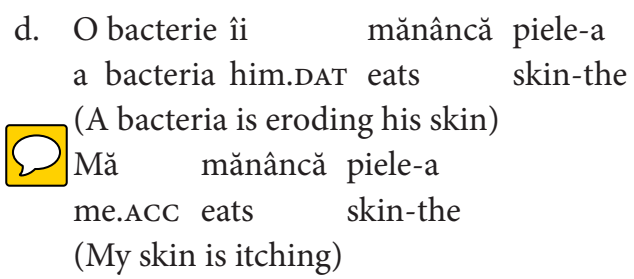

In summary, all of these verbs (except for durea 'ache' and furnica 'tingle') display a causative alternation in which the body part NP can occur either as the subject or the object of the verb (cf. (11)-(13), (14)). The case of the experiencer argument is dependent on the syntactic function of the body part NP: dative when this $\mathrm{NP}$ is an object, accusative when it is a grammatical subject.

\section{3. $\left[M \breve{a} \mathrm{~V}_{\text {pain }} \mathrm{NP}_{\text {body part }}\right]$ : Identifying subjects and objects}

This section will concentrate on the accusative structure in (1). More specifically it will address the question to what extent each of the two arguments displays subject or object properties.

\subsection{Is the body part NP a real subject?}

As noted before, the body part NP triggers verb agreement and is thus the grammatical subject of the clause.
a. Mă
doare capul
b. Mă dor picioare-le
me.ACC hurts head-the
(I have a headache)
me.ACc hurt feet-the
(My feet hurt)

Given its semantic role of theme, the question arises whether it behaves as a subject in other respects. The most obvious test comes from word order. Romanian is basically a SVO language, but its word order is quite flexible, so that the subject can be easily postposed to the right of the verb. Interestingly, a corpus investigation of each verb with its most frequent subject, both singular and plural (cf. Table 1), shows that the subject occurs far more frequently in postverbal position than in its canonical position before the verb.

For all verbs, the inverted word order is the most frequent, which suggests that the NP is a VP-internal argument (cf. also C. Cilianu-Lascu 2006). Nevertheless, frequencies vary according to the number of the subject, inversion being much more frequent in the singular $(85.99 \%)$ than in the plural $(67.86 \%)$. This 


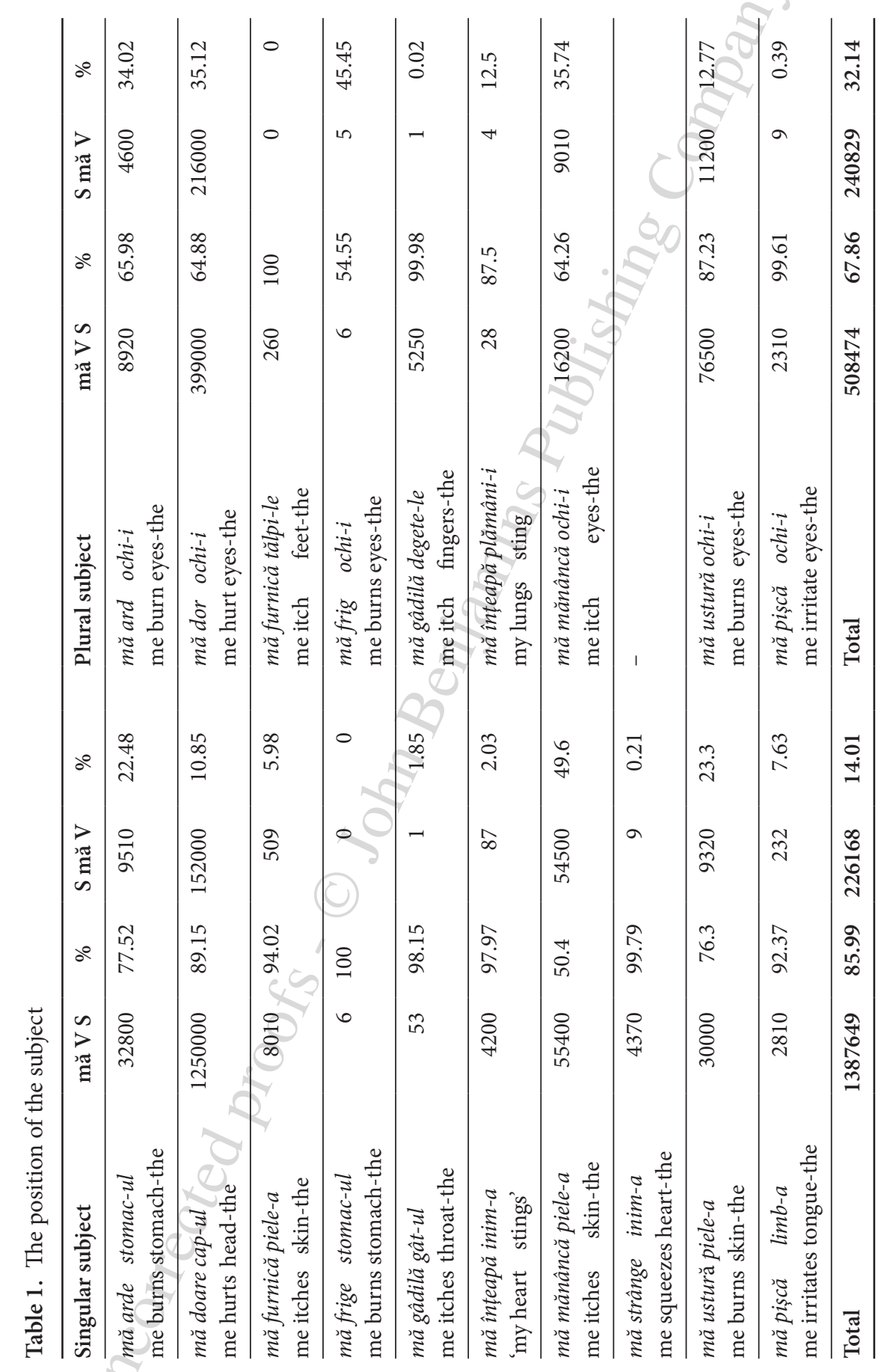


may be explained by the fact that, with most verbs, the agreement is morphologically more marked in the plural than in the singular. However, verbs of the first conjugation, such as ustura 'burn', înţepa 'sting', furnica 'tingle', and gâdila 'tickle', do not show a morphological difference between their singular and plural forms in the present tense, and yet furnica, gâdila, întepa occur the most with an inverted subject. By contrast, mânca 'eat', the most metaphorical of the 10 verbs, occurs very easily with both word orders. The relatively high frequency of the non-inverted word order could be explained in this case by the fact that the subject NP is more easily viewed as an external argument. Further investigation is required to evaluate the impact of the metaphorical use of these verbs on the word order of their arguments.

Another fact which supports the analysis of the body part NP as an internal argument is that it can be encoded as a locative PP in an impersonal construction, as in (16).

(16) a. Mă doare în piept / în partea stângă / în suflet / la inimă / înspate me.ACc aches in chest/in part left / in soul / in heart/ in back (I have pain in my chest / on the left side / in my soul / in my heart / in my back)

b. Mă înţeapă la inimă / la buric / la plămâni me.ACC stings in heart / in belly / in lungs (My heart / my belly stings / my lungs sting)

As shown in Table 2, the verbs under investigation allow the alternation between

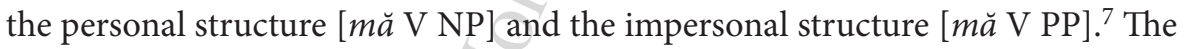
corpus investigation presented in Table 2 shows that the impersonal construction is used in almost a quarter of the examples (22.55\%). Again its frequency varies with the verb, but it is possible with all verbs.

Importantly, the experiencer argument bears accusative and not dative case. The accusative is thus assigned to the experiencer in the absence of a nominative, which goes against the hypothesis discussed above that sentences must have nominative case.

Another fact that supports a VP-internal analysis of the body part NP has already been mentioned in Section 2. Most verbs display a causative alternation, with the body part NP occurring either as the subject of a structure without an

7. I excluded the verb strânge 'tighten' because its use is mostly personal when occurring with a PP.

Mă strânge la piept şi-mi şopteşte la ureche: [...].

me.ACC pulls to chest and-me.DAT whispers to ear

'He pulled me to his chest and then whispers in my ear: [...]' 
Table 2. Impersonal vs. personal use of verbs of pain

\begin{tabular}{|c|c|c|c|c|c|}
\hline Impersonal construction & & $\%$ & Personal construction & 0 & $\%$ \\
\hline $\begin{array}{l}\text { mă doare in gât } \\
\text { me hurts in throat }\end{array}$ & 72200 & 33.09 & $\begin{array}{l}\text { mă doare gât-ul } \\
\text { me hurts throat-the }\end{array}$ & 146000 & 66.91 \\
\hline $\begin{array}{l}\text { mă arde în piept } \\
\text { me burns in chest }\end{array}$ & 110 & 10.52 & $\begin{array}{l}\text { mă arde piept-ul } \\
\text { me burns chest-the }\end{array}$ & 936 & 89.48 \\
\hline $\begin{array}{l}\text { mă furnică în tălpi } \\
\text { me itches in feet }\end{array}$ & 3 & 01.22 & $\begin{array}{l}\text { mă furnică tălpi-le } \\
\text { me itch feet-the }\end{array}$ & 242 & 98.78 \\
\hline $\begin{array}{l}\text { mă frige in stomac } \\
\text { me burns in stomach }\end{array}$ & 3 & 33.33 & $\begin{array}{l}\text { mă frige stomac-ul } \\
\text { me burns stomach-the }\end{array}$ & 6 & 66.67 \\
\hline $\begin{array}{l}\text { mă gâdilă în nas } \\
\text { me itches in nose }\end{array}$ & 170 & 45.70 & $\begin{array}{l}\text { mă gâdilă nas-ul } \\
\text { me itches nose-the }\end{array}$ & 202 & 54.30 \\
\hline $\begin{array}{l}\text { mă înţeapă la inimă } \\
\text { me stings to heart }\end{array}$ & 2910 & 06.47 & $\begin{array}{l}\text { mă îţeapă inim-a } \\
\text { me stings heart-the }\end{array}$ & 42100 & 93.53 \\
\hline $\begin{array}{l}\text { mă mănâncă în gât } \\
\text { me irritates in throat }\end{array}$ & 2600 & 97.12 & $\begin{array}{l}\text { mă mănâncă gât-ul } \\
\text { me irritates throat-the }\end{array}$ & 77 & 2.88 \\
\hline $\begin{array}{l}\text { mă ustură la ochi } \\
\text { me burns to eyes }\end{array}$ & 241 & 0.31 & $\begin{array}{l}\text { mă ustură ochi-i } \\
\text { me burn eyes-the }\end{array}$ & 76500 & 99.69 \\
\hline \multirow[t]{2}{*}{$\begin{array}{l}\text { mă pişcă la limbă } \\
\text { me irritates to tongue }\end{array}$} & 63 & 2.19 & $\begin{array}{l}\text { mă piscă limb-a } \\
\text { me irritates tongue-the }\end{array}$ & 2810 & 97.81 \\
\hline & 78300 & 22.55 & & 268873 & 77.45 \\
\hline
\end{tabular}

external argument or the object of a structure with an external argument. In the latter case, the external argument expresses the external cause of the pain and the experiencer is then obligatorily dative marked (cf. also (12)).

(17) a. Prea multe senzaţii îmi înțeapă inim-a, parcă ar too many sensations me.DAT sting heart-the, as.if have.cond

fi ace

be needles

(Too many sensations sting my heart, like needles)

b. Fumul îmi ustură ochi-i

smoke.the me.DAT burns eyes-the

(The smoke stung my eyes)

c. Aşa că am lăsat deoparte «răutate-a» care îmi

so that have.1 left to.a.side evil-the which me.DAT

furnică degete-le

ant.v fingers-the

(So I put aside the "evil" that made my fingers itch) 
As mentioned earlier, the transitive construction with an external argument is possible with all verbs of our list, except for durea 'hurt.' ${ }^{8}$ However, it is extremely rare with furnica 'itch' and ustura 'burn', although it is attested in examples $(17 b-c)$.

The three facts just presented support the analysis of the body part NP as an internal argument, hence a derived subject, and consequently the analysis of the verbs as unaccusative. Nevertheless, the following unaccusativity test does not corroborate this analysis for all verbs.

One of the most reliable criteria of unaccusativity is the use of the past participle as an adjectival modifier of the internal argument. This use is possible with the direct object of transitive verbs and with the subject of typically unaccusative verbs such as pleca 'leave', naşte 'be born', dispărea 'disappear', and sosi 'arrive' as in (18).

(18) a. Scrisoare-a, scrisă de mână, dar nedatată, este semnată cu letter-the written of hand but undated is signed with iniţialele C.L.

initials-the C.L.

(The letter, handwritten, but undated, is signed with the initials C.L.)

b. Copii-i născuţi la ţară nu sunt robotizaţi, au o lume children-the born at countryside not are robotized, have a world de basm

of fairy-tale

(The children born at the countryside are not robotized, they live in a fancy world)

c. Iniţiativă pentru copii-i dispăruţi

initiative for children-the vanished

(Initiative for lost children)

As for the verbs of pain, although most of them seem to allow their past participle to modify the body part NP as in (20), this use is ruled out with the most prototypical verb durea 'hurt', and also with furnica 'itch' and ustura 'burn' as in (19), precisely the three verbs which are not or not commonly used with an external argument. This suggests that the past participle construction is only possible when an external argument is present - overtly as in (20a) or covertly as in (20b).

8. A durea can be used with a causative meaning, but its use is then mostly intransitive and the experiencer can never occur in the dative.

(i) Adesea, pacienţi-i întreabă dacă implantul dentar doare sometimes patients-the ask whether implant-the dental hurts (Patients sometimes ask if a dental implant hurts) 
(19) a. ${ }^{\star}$ Am plecat cu cap-ul durut

have.1sG left with head-the hurt

b. ${ }^{\star} \mathrm{A}$ lucrat $\mathrm{cu}$ degete-le furnicate

has worked with fingers-the itched

c. ${ }^{\star A}$ lucrat la calculator cu ochi-i usturaţi de fum

Has worked at computer with eyes-the burnt by smoke

(20) a. Speriat, copilul cu ochi-i arşi de febră, a ridicat

frightened child-the with eyes-the burnt by fever, has shrugged

din umeri

of shoulders

(Frightened, the child with his feverish eyes, shrugged his shoulders)

b. Temuţi-i strigoi, cu inima înţepată şi arsă

feared-the ghost, with heart-the stung and burnt

(The feared ghosts, whose heart was stung and burnt)

c. Germani-i aşteaptă cu inim-a strânsă 100.000 de muncitori

Germani-the wait with heart-the squeezed 100,000 of workers

din est

from east

(The Germans are waiting with a fearful heart for 100,000 workers coming from the East)

In the same vein, passive is only possible with the verbs able to take external arguments, and not with those such as durea 'ache', ustura 'burn' and furnica 'tingle', which are rarely used with external arguments.

(21) a. Ochi-i lui Remy erau arşi de febră eyes-the GEN Remy were burnt of fever (Remy's eyes were glazed with fever)

b. Carnea îi / era mâncată de lepră the flesh him.DAT was eaten by leprosy (His flesh was eroded by leprosy)

(22) a. ${ }^{*}$ Cap-ul era durut head-the was ached

b. ${ }^{\star}$ Ochi-i erau usturaţi eyes-the were burnt

This shows that the use of the past participle is dependent on the presence of an external argument and is not valid as a test for the construction under investigation, where no such external argument is implied. In other words, three of the four tests argue in favor of a VP-internal analysis, while one test argues against it or is at least inconclusive. 


\subsection{Is the experiencer argument a real object?}

Let us now turn to the experiencer argument. In the construction under investigation, it bears morphological accusative case, which in Romanian is clearly distinct from the dative case in most pronouns. When the experiencer is a full NP, it is also clearly accusative marked; it is then preceded by the preposition pe, which marks animate definite object NPs in Romanian, and it is then mostly doubled by an accusative pronoun.

(23) a. Îl doare burt-a pe bebe him.ACC aches belly-the ACC baby (The baby has a stomach ache)

(24) b. L- am culcat pe bebe him.ACC have laid ACC baby (I laid the baby to sleep)

Morphologically it is thus clearly accusative-marked. Nevertheless, unlike other object NPs, it cannot become the subject of a passive construction (cf. (25)), nor can it be modified by the past participle corresponding to the verb (cf. (26)).
a. Mă doare cap-ul
me.ACC aches head-the
(I have a headache)
b. Mă ustură ochii.
me.Acc burn eyes-the
(My eyes are burning)
c. Mă gâdilă urechi-le
me.ACC itch ears-the
(My ears are itching)
vs. d. Mă deranjează zgomotul
Me.Acc disturbs noise-the (The noise disturbs me)

* Sunt durută de cap
am hurt by head

*Sunt usturată de ochi

am burnt by eyes

*Sunt gâdilată de urechi

am itched byears

Sunt deranjată de zgomot

am disturbed by noise

(I am disturbed by the noise)

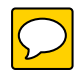

(26) a. ${ }^{\star P e r s o a n e-l e ~ d u r u t e ~[d e ~ c a p] . . . ~}$ persons-the hurt [by head]

b. ${ }^{*}$ Persoane-le usturate [de ochi] persons burnt [by eyes]

c. ${ }^{*}$ Persoane-le gâdilate [de urechi] persons itched [by ears]

vs. d. Cărţile citite de către studenţi ... books-the read by students (The books read by the students...) 
The above-mentioned data show that, although marked with the accusative, the experiencer does not behave as a prototypical object. Neither does the nominative theme behave as a prototypical subject. Therefore it is not surprising that verbs of pain, cross-linguistically, are the most likely to occur in non-canonical constructions or case frames (cf. G. Bossong 1998; M. Haspelmath 2001; I.A. Seržant 2013). The theme denoting the body part can be interpreted either as a stimulus, a patient or even as a location of the pain, and hence can be encoded either as a nominative subject, an accusative object (as in Lithuanian, cf. I.A. Seržant 2013), or a locative PP. As for the experiencer, because of its animacy and discourse salience, it tends to occur in sentence initial position and take on subject properties. Therefore, it develops in many languages into a dative subject or even a nominative subject, as in English and French (cf. 'I have a headache'). Only a few languages, mostly older languages (cf. Icelandic or German), assign the accusative to this experiencer argument, thus encoding it as a patient. In most of these languages, the accusative has been replaced with the dative (cf. old German Mich.ACC schmerzt der Kopf vs. Mod. German Mir.DAT schmerzt der Kopf), phenomenon called "dative sickness" by H. Smith (1994). In other words, the accusative experiencer found with verbs of pain in Romanian is archaic within the context of European languages. However, it does not trace back to Latin, which had a dative structure, just like Modern Spanish (cf. Latin Caput mihi.DAT $\left.\operatorname{dolet}^{9}\right)$. Diachronic research is necessary to give a better insight into this very particular evolution of Romanian, where the dative experiencer has apparently been replaced by an accusative one with a few prototypical verbs of pain such as durea 'ache', ustura 'burn', and has also attracted into this pattern metaphorical verbs of pain, such as arde 'burn' and mânca 'eat' / 'itch'. This evolution is surprising since Romanian is even more "dative-experiencer oriented" than other Romance languages (cf. G. Bossong 1998) and uses the dative case frame with a wide range of verbs of pain that we will comment on in the next section.

\section{Verbs of pain and the opposition accusative vs. dative subjects}

Indeed, as mentioned above, verbs of pain without an external argument do not necessarily assign accusative case to the experiencer argument in Romanian. The dative is used obligatorily with all verbs of pain that are not included in the list in (10) (cf. (27)) and it is also mandatory in reflexive constructions, as in (28).

9. Note that LAT. dolet is the etymon of ROM. doare. 
(27) a. Îmi / *Mă bate / tresare / vibrează inim-a me.DAT / ${ }^{\star}$ me.ACC beats / jumps / thrills heart-the (My heart is beating / is jumping / is thrilling)

b. Îmi / *Mă merge / vâjâie / vuieşte / pocneşte cap-ul me.DAT / ${ }^{\star}$ me.ACC goes / hums / hums / explodes head-the (My head is working / humming / humming / exploding)

(28) a. Mi se rupe / topeşte inim-a me.DAT REFL breaks / melts heart-the (My heart breaks / is melting)

b. $\mathrm{Mi}$ se strânge stomac-ul me.DAT REFL squeezes stomach-the (My stomach is tightening)

Both constructions are productive in that they can be instantiated by a wide range of verbs. The construction in (27) is used with intransitive verbs or verbs used intransitively that express a process taking place within the body part and affect the experiencer only indirectly. ${ }^{10}$ As for the reflexive construction in (28), it is used with causative verbs in their intransitive use giving rise to an anticausative construction; from a semantic point of view these verbs express a change of state taking place within the body part. ${ }^{11}$

Both the accusative and the dative experiencer display subject properties in that they bind the definite article of the body part NP, as already noted earlier in Section 1.1, and can control the subjects of gerunds as in (29)-(30). This behavior argues in favor of an analysis of both accusative and dative nominals in this construction as quirky subjects.

(29) a. Te doare suflet-ul văzând imagine-a!!! you.Acc aches soul-the seeing image-the (Your heart breaks when you see this image)

b. Mi se strânge inim-a de multe ori văzând ce se me.DAT REFL squeezes heart-the of many times seeing what REFL întâmplă în România happens in Romania (My heart often shrinks when I see what is happening in Romania)

10. The construction [îmi.DAT $\mathrm{V} \mathrm{NP}_{\text {body part }}$ ] is used with verbs such as: țiui 'ring', amorți 'numb'
bate 'beat', crăpa 'split', curge 'run', lacrima 'tear', pocni 'hit', tremura 'shake', trosni 'crackle', etc.

11. Other verbs that enter in this construction are: a se infunda 'get blocked', a se incinge 'hot', $a$ se învineţi 'bruise', a se coji 'peel', a se topi 'melt', a se înroși 'redden', a se mişca 'move', a se bloca 'block', a se usca 'dry', a se încălzi 'warm', etc. 
(30) a. Îmi sângerează inim-a văzând cum este ignorată Iubire-a Mea me.DAT bleeds heart-the seeing how is ignored love-the mine (My heart bleeds when I see how my love is ignored)

b. Îmi vâjâie cap-ul doar citind despre aceste nesfârşite me.DAT howls head-the only reading about these endless plimbări de la un ghišeu la altul. walks from a counter to other (My head spins when I read about about those endless walks from one counter to another)

What is important to note is that the accusative and the dative are almost always mutually exclusive. Although Table 3 seems to suggest that some of the accusative verbs in the list in (8) can assign the dative to the experiencer, a closer look at the examples shows that the dative case is only used when an external argument is present.

The only exception is arde 'burn', one of the most typical verbs of the causative/anticausative alternation. I claim that the indeterminacy of arde as to the case

Table 3. Accusative vs. dative case

\begin{tabular}{|c|c|c|c|c|c|}
\hline + accusative & & $\%$ & + dative & & $\%$ \\
\hline $\begin{array}{l}\text { mă doare cap-ul } \\
\text { me.Acc hurts head-the }\end{array}$ & 1370000 & 99.99 & $\begin{array}{l}\hat{\imath} m i \quad \text { doare cap-ul } \\
\text { me.DAT hurts head-the }\end{array}$ & 2 & 0.01 \\
\hline $\begin{array}{l}\text { mă arde piept-ul } \\
\text { me.ACc burns chest-the }\end{array}$ & 1040 & 45.41 & $\begin{array}{l}\text { imi arde piept-ul } \\
\text { me burns chest-the }\end{array}$ & 1250 & 54.59 \\
\hline $\begin{array}{l}\text { mă furnică degete-le } \\
\text { me.ACC itch feet-the }\end{array}$ & ${ }_{0}^{31400}$ & 99.99 & $\begin{array}{l}\text { immi furnică degete-le } \\
\text { me.DAT itch feet-the }\end{array}$ & 16 & 0.01 \\
\hline $\begin{array}{l}\text { mă frige stomac-ul } \\
\text { me.Acc burns stomach-the }\end{array}$ & 9850 & 100 & $\begin{array}{l}\text { imi frige stomac-ul } \\
\text { me.DAT burns stomach-the }\end{array}$ & 0 & 0 \\
\hline $\begin{array}{l}\text { mă gâdilă nas-ul } \\
\text { me.Acc itches nose-the }\end{array}$ & 178 & 2.16 & $\begin{array}{l}\hat{\imath} m i \quad g \hat{a} d i l a ̆ \text { nas-ul } \\
\text { me.DAT itches nose-the }\end{array}$ & 8060 & 97.84 \\
\hline $\begin{array}{l}\text { mă inţeapă inim-a } \\
\text { me.Acc stings heart-the }\end{array}$ & 46200 & 98.1 & $\begin{array}{l}\hat{i m i} \text { inţeapă inim-a } \\
\text { me.DAT stings heart-the }\end{array}$ & 893 & 1.9 \\
\hline $\begin{array}{l}\text { mă mănâncă piele-a } \\
\text { me.Acc irritates skin-the }\end{array}$ & 60300 & 99.99 & $\begin{array}{l}\text { immi mănâncă piele-a } \\
\text { me.DAT irritates skin-the }\end{array}$ & 2 & 0.01 \\
\hline $\begin{array}{l}\text { mă ustură ochi- } i \\
\text { me.Acc burn eyes-the }\end{array}$ & 81100 & 99.99 & $\begin{array}{l}\hat{i m i} \quad \text { ustură ochi-i } \\
\text { me.DAT burn eyes-the }\end{array}$ & 499 & 0.01 \\
\hline $\begin{array}{l}\text { mă pişcă limb-a } \\
\text { me.ACC irritates tongue-the }\end{array}$ & 2570 & 99.69 & $\begin{array}{l}\text { îmi pişcă limb-a } \\
\text { me.DAT irritates tongue-the }\end{array}$ & 8 & 0.31 \\
\hline $\mathrm{N}$ & 1561408 & 99.38 & & 9762 & 0.62 \\
\hline
\end{tabular}


of the experiencer can be explained by the fact that, because of the causative/anticausative alternation, it is as frequent in intransitive as in transitive constructions and can therefore be used both in the accusative construction, which hosts transitive verbs, and in the dative construction illustrated in (31), which is typically used with intransitive verbs.

(31) a. Am avut febră cu frisoane şi senzaţi-a că îmi arde have.1 had fever with chills and feeling-the that me.DAT burns piept-ul acum vreo 5 zile de am dat fugă la urgenţe chest-the now about 5 days that have. 1 given run to emergency (I had fever with chills and the feeling that my chest was burning about 5 days ago, so that I ran to the emergency)

b. Dragul meu, te privesc şi simt că îmi arde dear-the mine you.ACC watch and feel.1 that me.DAT burns piept-ul chest-the (My dear, I look at you ant I feel that my chest is burning)

(32) a. Simţea-m soarele cum îmi arde pieptul felt-1 sun-the how me.DAT burns chest-the (I felt how the sun burned my chest)

b. Aer-ul aspru îmi arde piept-ul air-the harsh me.DAT burns chest-the (The harsh air is burning my chest)

An important difference between the accusative and the dative subject construction is that the accusative is assigned by a very limited set of verbs, whereas the dative is used with a broad set of intransitive and reflexive verbs. In other words, the dative subject structure is productive, whereas the accusative one is not. A possible explanation is that case is not assigned in the same way in these two structures. I will argue that the accusative is assigned to a verb argument and is a lexical case, whereas the dative is assigned to an external possessor and is an inherent case, in line with E. Woolford (2006:113), who defines lexical case as "idiosyncratic, lexically selected case" and inherent case as "a case inherently associated with certain $\theta$-roles/positions": lexical case "may occur on themes/ internal arguments" and inherent case "on agentive/external arguments and on (shifted) DP goal argument, but not on themes/internal arguments". Lexical case is licensed by lexical heads, whereas inherent case is licensed by "little/light $\mathrm{v}$ heads" to arguments occurring above the VP.

This analysis is supported by the fact that, being an external possessor, the dative experiencer is highly dependent on the encoding of the body part NP, which has to be as an object or a derived subject, in other words a VP-internal NP. In 
contrast, the accusative experiencer is not dependent on the syntactic encoding of the theme argument, which can be a subject or a locative PP, as shown above (cf. the examples in (16) above), or even an adverb in an impersonal construction.
a. Unde te / *îti doare? where you.ACC $/{ }^{*}$ you.DAT aches (Where does it hurt?) me.ACC / me.DAT stings down when urinate.1 (It stings down there when I urinate)
b. Mă / *îmi ustură jos când urinez

Moreover, an accusative subject allows the theme argument to be absent, as in the examples in (34), where the referent of the theme is difficult to identify, which shows that there is no zero anaphora. This structure is particularly frequent with the verbs durea 'ache' and ustura 'burn', in their impersonal form, but it is excluded with dative subjects.
a. Te / *îţ̧i doare când naşti?
you.ACC / *you.DAT aches when gives.birth
(Does it hurt when you give birth?)
b. Te / *îţ̧i ustură când urinezi?
you.ACC / *you.DAT burns when urinate.2
(Does it burn when you urinate?)

The fact that with accusative subjects the theme argument can easily alternate with a locative PP or with an adverb and can even be absent makes the theme more adjunct-like, presenting it as the location of the pain, while the experiencer is the most salient argument, directly affected by the verb. Therefore the verb has to express pain that directly affects the experiencer, giving rise to a metonymical interpretation according to which the whole person is affected by the process. By contrast, the dative subject can be used with processes occurring within the body part, but which cannot take the experiencer as a whole as an argument.

This leads to the surprising conclusion that the accusative in the construction under investigation is even more subjectlike than the dative, although dative subjects are much more common in Romanian: the accusative subject is a verb argument, whose encoding does not depend on the encoding of other arguments, and it can be used as the sole argument. As for the dative subject, like external possessors it is not an argument of the verb, but of the body part noun, and is therefore highly dependent on the encoding of the body part NP. 


\section{Conclusions}

The analysis of the accusative construction $\left[m \breve{a} \mathrm{~V}_{\text {pain }} \mathrm{NP}_{\text {body part }}\right]$ in Romanian argues against the claim that the accusative is dependent on the licensing of the nominative, in that it shows that the accusative can be assigned in constructions lacking a nominative. It has also shown that the accusative displays subject behavior in this construction, just like the dative in similar constructions. The accusative is assigned to verbal arguments, whereas the dative is used with external possessors taking on subject behavior. The argument status of the argument experiencer makes it more subjectlike than the dative in that the former is not dependent on the presence and the encoding of another argument, whereas the dative subject necessarily co-occurs with an internal argument denoting the body part encoded as a grammatical subject triggering verb agreement.

Further investigation is needed to provide a more complete account of accusative and dative subjects in Romanian, accusative subjects being much rarer than dative subjects in Romanian and in Romance in general. Given the relatively higher frequency of accusative subjects in Slavic languages than in Romance, the question arises to what extent this Romanian construction is a result of the influence from Slavic languages or even German, which has similar accusative subjects (cf. mich/mir schmerzt der Kopf), a question which can only be addressed in a study with a much broader comparative and diachronic perspective.

\section{References}

Barnes, Michael. 1986. Subject, nominative and oblique case in faroese. Scripta Islandica 37. $13-46$.

Belletti, Adriana \& Luigi Rizzi. 1988. Psych-verbs and theta theory. Natural Language and Linguistic Theory 6. 291-352. doi:10.1007/BFoo133902

Bennis, Hans. 2004. Unergative adjectives and psych verbs. In A. Artemis, E. Anagnostopoulou, \& M. Everaert (eds.), The unaccusativity puzzle. Explorations of the syntax-lexicon interface, 84-113. Oxford: Oxford University Press. doi:10.1093/acprof:oso/9780199257652.003.0004

Bonch-Osmolovskaya, Anastassia, Ekaterina V. Rakhilina \& Tatiana I. Reznikova. 2007. Conceptualization of pain: A database for lexical typology. In P. Bosch, D. Gabelaia, \& J. Lang (eds.), TbiLLC 2007, LNAI, 110-123. Berlin/Heidelberg: Springer Verlag.

Bossong, Georg. 1998. Le marquage de l'expérient dans les langues de l'Europe. In J. Feuillet (ed.), Actance et valence dans les langues de l'Europe, 259-294. Berlin/New York: Mouton/ de Gruyter.

Burzio, Luigi. 1981. Intransitive verbs and italian auxiliaries. Ph.D. diss. MIT.

Burzio, Luigi. 1986. Italian syntax: A Government binding approach. Dordrecht: Reidel. doi:10.1007/978-94-009-4522-7 
Burzio, Luigi. 2000. Anatomy of a generalization. In E. Reuland Eric (ed.), Arguments and case. Explaining burzio's generalization, 195-240. Amsterdam: John Benjamins. doi:10.1075/la.34.10bur

Chomsky, Noam. 1986. Barriers. Cambridge, MA: MIT Press.

Cilianu-Lascu, Corina. 2006. O mănâncă limba/la langue lui démange. Quelques remarques sur la place du sujet dans les structures possessives en roumain et en français, Enonciation et syntaxe. Recherches ACLIF: Actes du Séminaire de Didactique Universitaire, Association des Chercheurs en Linguistique Française 3. 51-69.

Guéron, Jacqueline. 1983. L’emploi possessif de l’article français. Langue française 58. 23-35. doi:10.3406/Ifr.1983.6413

Guéron, Jacqueline. 1985. Inalienable possession, pro-inclusion and lexical chains. In J. Guéron, H. Obenauer, \& J.-Y. Pollock (eds.), Grammatical representation, 43-86. Dordrecht: Foris.

Guéron, Jacqueline. 2003. Inalienable possession and the interpretation of determiners. In M. Coene Martine \& Y. D'hulst (eds.), The expression of possession in noun phrases. From NP to DP, Vol. II, 189-220. Amsterdam: John Benjamins. doi:10.1075/la.56.13gue

Guéron, Jacqueline. 2007. Inalienable possession. In M. Everaert \& H. van Riemsdijk (eds.), The blackwell companion to syntax, 589-638. Malden: Blackwell Publishing.

Haider, Hubert. 2000. The license to license: Licensing of structural case plus economy yields burzio's generalization. In E. Reuland (ed.), Arguments and case. Explaining burzio's generalization, 31-56. Amsterdam: John Benjamins. doi:10.1075/la.34.05hai

Haspelmath, Martin. 2001. Non-canonical marking of core arguments in European languages. In A. Aikhenvald, Y. Alexandra, R. M. W. Dixon, \& M. Onishi (eds.), Non-canonical marking of subjects and objects, 53-83. Amsterdam: John Benjamins. doi:10.1075/tsl.46.04has

Herschensohn, Julia. 1992. French inalienable binding. In C. Laeufer \& T. A. Morgan (eds.), Theoretical analyses in romance linguistics, 367-384. Amsterdam: John Benjamins. doi:10.1075/cilt.74.24her

Junker, Marie-Odile, \& France Martineau. 1987. Les possessions inaliénables dans les constructions objet. Revue romane 22. 194-209.

Kleiber, Georges. 1999. Anaphore associative et relation partie-tout: condition d'aliénation et principe de congruence ontologique. Langue française 122. 70-100. doi:10.3406/lfr.1999.6288

König, Ekkehard, \& Martin Haspelmath. 1998. Les constructions à possesseur externe dans les langues d'Europe. In J. Feuillet (éd.), Actance et valence dans les langues d'Europe, 525-606. Berlin: Mouton de Gruyter.

Marantz, Alec. 2000. Case and licensing. In Reuland Eric (ed.), Arguments and case. Explaining burzio's generalization, 11-30. Amsterdam: John Benjamins. doi:10.1075/la.34.04mar

Perlmutter, David M. 1978. Impersonal passive and the unaccusative hypothesis. Proceedings of the 4th Annual Meeting of the Berkeley Linguistics Society (BLS 4), 159-189.

Perlmutter, David M. \& John Moore. 2002. Language-Internal explanation: The distribution of Russian impersonals. Language 78. 373-416. doi:10.1353/lan.2003.0049

Reuland, Eric. (ed.).2000a. Arguments and case. Explaining burzio's generalization. Amsterdam: John Benjamins. doi:10.1075/la.34

Reuland, Eric. 2000b. Explaining burzio's generalization: Exploring the issues. In E. Reuland (ed.), Arguments and case. Explaining burzio's generalization, 1-10. Amsterdam: John Benjamins. doi:10.1075/la.34.03reu 
Riegel, Martin. 1994. Article défini, anaphore intra-phrastique et relations partie-tout. In C. Schnedecker, et al. (eds.), Lanaphore associative (Aspects linguistiques, psycholinguistiques et automatiques), 233-250. Paris: Klincksieck.

Schnedecker, Catherine, Charolles Michel, Kleiber Georges \& David Jean (eds.). 1994. L'anaphore associatiave (Aspects linguistiques, psycholinguistiques et automatiques). Paris: Klincksieck.

Şerbănescu, Andra. 1999. Dativ posesiv, dativ experimentator. Studii şi cercetări lingvistice L, 1. 19-38.

Seržant, Ilja A. 2013. Rise of canonical objecthood with the Lithuanian verbs of pain. Baltic Linguistics 4. 187-211.

Smith, Henry. 1994. "Dative sickness" in Germanic. Natural Language and Linguistic Theory 12. 675-736. doi:10.1007/BFoog92930

Spanoghe, Anne-Marie. 1995. La syntaxe de l'appartenance inaliénable en français, en espagnol et en portugais. Frankfurt am Main: Peter Lang.

Van Peteghem, Marleen. 2006a. Le datif en français: un cas structural. Journal of French Languages Studies 16. 93-110. doi:10.1017/So959269506002286

Van Peteghem, Marleen. 2006b. Anaphores associatives intra-phrastiques et inaliénabilité. In M. Riegel, C. Schnedecker, P. Swiggers, \& I. Tamba (eds.), Aux carrefours du sens. Hommages offerts à Georges Kleiber pour son 60e anniversaire, 441-456. Leuven: Peeters.

Vergnaud, Jean-Roger \& María Luisa Zubizaretta. 1992. The definite determiner and the inalienable construction in French and English. Linguistic Inquiry 23. 595-652.

Woolford, Ellen. 2003. Burzio's generalization, markedness, and locality constraints on nominative objects. In E. Brandner \& H. Zinsmeister (eds.), New perspectives on case theory, 299-327. Stanford: CSLI Publications.

Woolford, Ellen. 2006. Lexical case, inherent case, and argument structure. Linguistic Inquiry 37(1). 111-130. doi:10.1162/002438906775321175 